\title{
Pharmacognosic standardization of a traditional recipe for incurable wounds based on Petersianthus macrocarpus (Lecythidaceae), Vernonia conferta (Asteraceae), and Carica papaya (Caricaceae) in Cameroon
}

\begin{abstract}
Standardization is a process that allows botanical, chemical, pharmacognosic or even pharmacological characterization of herbal medicines. This operation will consist of a macroscopic and microscopic examination of the medicinal material of the recipe (remedy's mixture of powders). Then, a phyto chemical screening of the extract prepared in accordance with the practices of the healer will be carried out. Finally, the desiccation loss and the total ash content will be determined. The recipe used for incurable wounds was obtained following an ethno botanical survey carried out with a traditional healer. Indeed, traditional medicine continues to provide therapeutic solutions through plants. Chronic wounds are severe affections by their manifestations. Their care is difficult because of the multitude of factors behind their constitution. Many conventional therapies are available but mostly unaffordable and less and less effective. The goal of this work was to develop a new affordable and effective treatment. Our work has therefore successfully standardized a traditional recipe based on Petersianthus macrocarpus (Lecythidaceae), Vernonia conferta (Asteraceae), and Carica papaya (Caricaceae), used locally in the treatment of chronic wounds. This research is part of the program initiated by Abondo-Ngono Mballa et al.,1 on cartography of Healers from the Center Region Cameroon, followed by Ngono Mballa et al.,2 and Minyem et al.,3 in standardization of a recipe traditionally used to cure scalp fungal dermatitis. The standardization approach is therefore the appropriate solution to identify chemical and biochemical markers, constituting the substances and compounds of the plants present in the recipe and which would be responsible for the therapeutic activity.
\end{abstract}

Keywords: chronic wounds, traditional medicine, standardization, bark
Volume 7 Issue 2 - 2019

\author{
Ngono Mballa Rose,,,$^{3}$ Wokam Michèle \\ Noël, ${ }^{2}$ Wouessidjewe Denis, ${ }^{4}$ Minyem \\ Aude Perrine, ${ }^{3}$ Ngoupayo Joseph, ${ }^{5}$ Beyene \\ Victorine ${ }^{6}$ \\ 'Départment of Pharmacology and Traditional Medicine, Faculty \\ of Medicine and Biomedical Sciences, Yaoundé I University, \\ Cameroon \\ ${ }^{2}$ Université des Montagnes, Cameroon \\ ${ }^{3}$ National Drug Quality Control and Valuation Laboratory, \\ Cameroon \\ ${ }^{4}$ Département de Pharmaco chimie Moléculaire, Université de \\ Grenoble Alpes, France \\ ${ }^{5}$ Department of Therapeutic Chemistry and Pharmacognosy, \\ Faculty of Medicine and Biomedical Sciences, Yaoundé I \\ University, Cameroon \\ ${ }^{6}$ Plantes Médicinales Héritage Africain, Cameroon
}

\section{Correspondence: Ngono Mballa Rose, Départment of Pharmacology and Traditional Medicine, Faculty of Medicine and Biomédical Sciences, Yaoundé I University, Cameroon,} Email princessrose@hotmail.fr

Received: March 27, 2019 | Published: April 09, 2019

\section{Introduction}

Wounds are break-ins of the cutaneous barrier. They fall into two broad categories: acute wounds and chronic wounds. ${ }^{4}$ The chronic wounds are characterized by an extended healing time ( 4 to 6 weeks of evolution, depending on the etiology). ${ }^{5}$ Their prevalence in the general population is estimated at $1 \%$ and their prevalence in the population over 65 years of age, is at up to 3 to $5 \%{ }^{6}$ In a context of low affordability in access to expensive care, combined with the resistance of microorganisms to anti-infectives, exploring the vast reservoir of natural resources like medicinal plants is a preferred pathway. ${ }^{7}$ In fact, and in general in Africa, about $80 \%$ of the population uses traditional medicine. ${ }^{8}$ In addition, traditional healers have always been the primary caregivers of many patients with limited resources, and some of them are well recognized in their respective communities. Therefore it is necessary to search in the therapeutic heritage of our recipes/traditional remedies, with a view to standardize these very products, in order to ameliorate the quality. Standardize means implement quality procedures at all stages of manufacture, from the crude drug to the extract, to achieve a specified known or required standard. All the parameters influencing the quality of the product (extract, finished product) must be defined, followed and applied from the raw material (its origin, the cultivation methods, the concern part of the plant, its identity, its purity, its active principle content), but also the nature and concentration of the extraction solvent, as well as the manufacturing process (maceration/percolation, temperature, time, pressure during manufacture, drying process, controls during manufacture). ${ }^{9}$ Standardization therefore, consists in ensuring a constant pharmaceutical quality for a herbal medicine. A study conducted in the Center region had made possible, to establish an almost exhaustive list of recipes, used by many traditional healers to treat several types of affections. ${ }^{1}$ Then, we decided to standardize a traditional recipe for the treatment of chronic wounds, found in the above mentioned document, which was made up by three plants: Petersianthus macrocarpus (Lecythidaceae), Vernonia conferta (Asteraceae), and Carica papaya (Caricaceae). 


\section{Material and methods}

\section{Vegetable equipment}

It was harvested in February 2017 in the Central Region in Mbankomo, department of Méfou-et-Akono. The identification was made at the National Herbarium of Cameroon. The stem bark of Petianthus macrocarpus was identified by comparison with the sample of Endengle Elias No. 187 (19089/HNC), collected on $07 / 03 / 1996$. The trunk bark of Vernonia conferta was identified by comparison with the Duncan W. Thomas sample No. 6847 (55447/ HNC), collected on 25/03/1987. Carica papaya root barks was identified by comparison with the ECOFAC sample No. 999 (66220/ HNC), collected on 08/09/1995. After the macroscopic analysis, the barks were dried-shading during a week and then, grounded with an electric crushing mill.

\section{Macroscopic examination ${ }^{10}$}

Whole barks were examined and manipulated to measure the thickness, to identify the color, the texture, the degree of fragility, the characteristics of fissures, and finally the strength and odour feeling.

\section{Microscopic examination"}

In a lab recipient, powders were wetted firstly with distilled water, and secondly with a $5 \% \mathrm{w} / \mathrm{v}$ aqueous solution of sodium hydroxide (with a view to completely or partially destroying certain elements as plant cells, may be include or not in parenchymal cells, in order to rend cell walls sharper and easier to observe, specially the sclerified elements, fibers and cuticles). Samples were then observed under the optical microscope CAMERA IRMECO ${ }^{\circledR}$.

\section{Pharmacognosic standardization of recipe (Traditional Remedy)}

It involved carrying out testing to characterize the components present in the recipe and which may be responsible for its activity, i.e a phytochemical screening. ${ }^{12}$ Then we performed two quality control testing's of plant materials, loss on drying and total ash content, according to WHO Guidelines. ${ }^{10}$

\section{Extraction}

To $75 \mathrm{~g}$ of powder we added $150 \mathrm{ml}$ of distilled water and brought the mixture to boil during 15 minutes. The filtrate obtained was reduced by evaporation, to obtain a weight equal to the mass of initial plant material (fluid extract).

\section{Search for flavonoids}

To an aliquot of decoction, we added few drops of ethanol $\left(\mathrm{C}_{2} \mathrm{H}_{5} \mathrm{OH}\right)$, hydrochloric acid $(\mathrm{HCl})$ and some magnesium slices. The appearance of pink-orange or purplish color was an indication of positive reaction.

\section{Search for alkaloids}

In two test tubes, an aliquot acidified decoction with hydrochloric acid was distributed; we add few drops of Dragendorff's reagent in one, and in the other, drops of Mayer reagent. The appearance of orange-red precipitate or a ladle was an indication of positive test.

\section{Search for tannins}

To an aliquot decoction we add $15 \mathrm{ml}$ of Stiasny's reagent. The presence of a brown precipitate was an indication of catechic tannins presence. On the filtrate of the previous mixture, we add few drops of iron chloride III $\left(\mathrm{FeCl}_{3}\right)$ at $2 \%$. The appearance of a blue-black color indicated the gallic tannins presence.

\section{Search for saponosides}

We introduced $5 \mathrm{ml}$ of decoction into a test tube and stirred vigorously for $2 \mathrm{~min}$. The formation of a foam (height greater than 1 $\mathrm{cm}$ ) stable, persisting in 15 minutes indicated saponins presence.

\section{Search for steroids and terpenoids}

To an aliquot decoction, we added $1 \mathrm{ml}$ of acetic anhydrous $\left(\mathrm{C}_{4} \mathrm{H}_{6} \mathrm{O}_{3}\right)$ and $0.5 \mathrm{ml}$ of concentrated sulfuric acid $\left(\mathrm{H}_{2} \mathrm{SO}_{4}\right)$. The appearance of a purple color that turns blue then green indicated the presence of sterols, while the appearance of a red ring indicated the presence of polyterpens.

\section{Search for coumarines}

To an aliquot decoction, we added ethanol and then divided into two test tubes. To one, we added $0.5 \mathrm{ml}$ of $10 \%$ sodium hydroxide $(\mathrm{NaOH})$, and then the tubes were heated in a water bath until boiling. After cooling, we added in each tube, $4 \mathrm{ml}$ of distilled water and few drops of concentrated hydrochloric acid. The formation of a precipitate in the tube containing the mixture indicated a positive reaction.

\section{Search for bound quinones}

To an aliquot decoction, we added $5 \mathrm{ml}$ of hydrochloric acid diluted to $1 / 5$ and heated all in boiling water bath for $30 \mathrm{~min}$. After cooling, the organic phase was extracted with $20 \mathrm{ml}$ of chloroform $\left(\mathrm{CHCl}_{3}\right)$ and a $50 \%$ dilution of ammonia $\left(\mathrm{NH}_{4} \mathrm{OH}\right)$ was added. The appearance of a hue ranging from red to purple indicated a positive reaction.

\section{Loss on drying}

$5 \mathrm{~g}$ of powder were deposited in a beaker previously dried, weighed and tarred, then heated in an oven at $105^{\circ} \mathrm{C}$ during 24 hours. The percentage of loss on drying was calculated according to the amount of initial powder.

\section{Total ash}

$2 \mathrm{~g}$ of powder were introduced into a crucible previously heated, weighed and calibrated, then heated to $500-600^{\circ} \mathrm{C}$, until the ashes become white. The total ash content was calculated based on the amount of initial powder.

\section{Results}

\section{Macroscopic examination}

The different observations are mentioned in Table 1.

\section{Microscopic examination}

Figure 1, Figure 2 \& Figure 3

\section{Extraction}

The different extraction yields, calculated for the aqueous extracts and the hydro-alcoholic extracts, are listed in Table 2.

\section{Phytochemical screening}

The different secondary metabolites found are listed in Table 3. 
Analysis of the phytochemical composition revealed the presence of alkaloids, catechic tannins and terpenoids in the trunk bark of Vernonia conferta, tannins, saponosides, terpenoids and bound quinones in the bark of Petersianthus macrocarpus trunk, and terpenoids in the root bark of Carica papaya.

\section{Physicochemical testing's}

The percent losses of desiccation and total ash measured are shown in Table 4 below.

Table I Macroscopic physical characteristics of cark

\begin{tabular}{llll}
\hline & Trunk bark of Vernonia conferta & Trunk bark of Petersianthus macrocarpus & Root bark of Carica papaya \\
\hline Dimensions (mm) & $3-5^{*}$ & $4-7^{*}$ & $8-220^{* *}$ \\
External color & Black green & Brown & Milky \\
Internal color & Dark brown & Brown & White \\
Texture & Tough & Tough & Fresh \\
Fissure plan & Fibrous & Fibrous & Smooth \\
Smell of the powder & Distinct, acrid & Weak & Distinct, fruity and spicy \\
\hline
\end{tabular}

*Thickness

**Diameter

Table 2 Extraction yields

\begin{tabular}{llll}
\hline Initial powder masses & \multicolumn{2}{l}{ Masses of extracts obtained } & \multicolumn{2}{l}{ Yield } \\
\hline \multirow{2}{*}{ Vernonia conferta (100g) } & Aqueous extract & $5 \mathrm{~g}$ & $5 \%$ \\
& Hydro-alcoholic extract & $4.5 \mathrm{~g}$ & $4.5 \%$ \\
Petersianthus macrocarpus (I00g) & Aqueous extract & $9.3 \mathrm{~g}$ & $9.3 \%$ \\
& Hydro-alcoholic extract & $11.4 \mathrm{~g}$ & $11.4 \%$ \\
Carica papaya (100g) & Aqueous extract & $6 \mathrm{~g}$ & $6 \%$ \\
& Hydro-alcoholic extract & $4.7 \mathrm{~g}$ & $4.7 \%$ \\
\hline
\end{tabular}

Table 3 Phytochemical compositions

\begin{tabular}{llll}
\hline & Trunk bark of Vernonia conferta & Trunk bark of Petersianthus macrocarpus & Root bark of Carica papaya \\
\hline alkaloids & + & - & - \\
Catechic tannins & + & ++ & - \\
Gallic tannins & - & +++ & - \\
saponosides & - & - & - \\
flavonoids & - & + & + \\
Terpenoids & ++ & - & - \\
Steroids & - & - & - \\
Coumarins & - & ++ & - \\
Linked quinones & - &
\end{tabular}

+: weakly present; ++: medium present; +++: highly present; -: absent

Table 4 Physico-chemical tests

\begin{tabular}{llll}
\hline & Vernonia conferta & Petersianthus macrocarpus & Carica papaya \\
\hline Loss on drying (\%) & 9.33 & 8.67 & 42.67 \\
Total ash (\%) & 7 & 5.2 & 11 \\
\hline
\end{tabular}

Citation: Rose NM, NoëlWM, Denis W, et al. Pharmacognosic standardization of a traditional recipe for incurable wounds based on Petersianthus macrocarpus (Lecythidaceae),Vernonia conferta (Asteraceae), and Carica papaya (Caricaceae) in Cameroon .Pharm Pharmacol Int J. 2019;7(2):86-9l. 


\section{Discussion}

After an ethnobotanical survey done by the traditional healer who conducted in harvesting plants, we carried out various testing on samples, in order to develop plant monographs. After a complete macroscopic analysis, the plants were crushed for microscopic analysis. The micrograph of Carica papaya (Figure 1) revealed the presence of calcium oxalate crystals and palissadic tissues, which is a conductive tissue. Roy et al. ${ }^{13}$ also found on trunk powder of Carica papaya, calcium oxalate crystals, with parenchymal cells and several conductive tissues. The analysis of Vernonia conferta powder (Figure 2) showed the presence of support tissues (collenchyme, suber, epidermis fragment covered with hair like outgrowth from the surface, sclerified fibers), conductive tissues (bast fibers), perimedullary tissue and calcium oxalate crystals. Evans et al., ${ }^{14}$ had observed irregular epidermal cells, anomocytic stomata, and T-shaped glandular hair like outgrowth from the surface. Singh et al., ${ }^{15}$ Vernonia cinerea bark cells, parenchymatous cells, hair like outgrowth from the surface, fibers and vessels were found on the powder of Vernonia cinerea bark. The micrograph of the bark powder of Petersianthus macrocarpus (Figure 3) showed the presence of secondary xylem, a mass of conductive tissue, fibers of the palissadic tissue and sclerotic cells. Lens et al., ${ }^{16}$ had observed inter alia axial parenchymal cells.

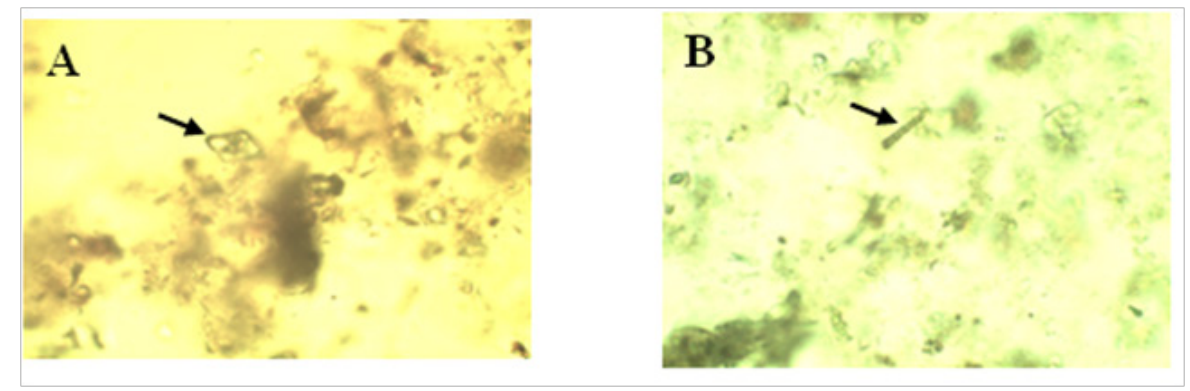

Figure I Micrograph of fresh roots of Carica papaya: observation with sodium hydroxide. (A) Calcium oxalate crystals. (B) Palisade tissue structure (conductive tissue) (Source: present study).
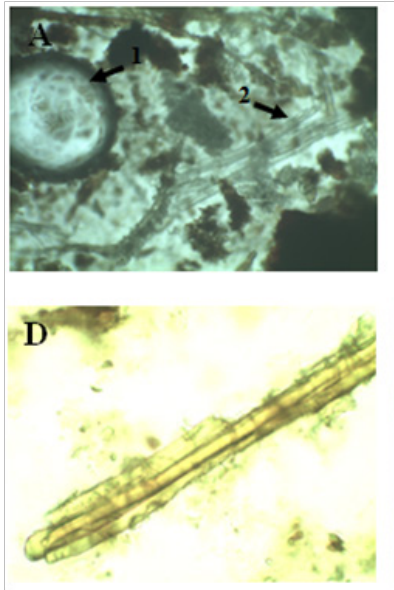
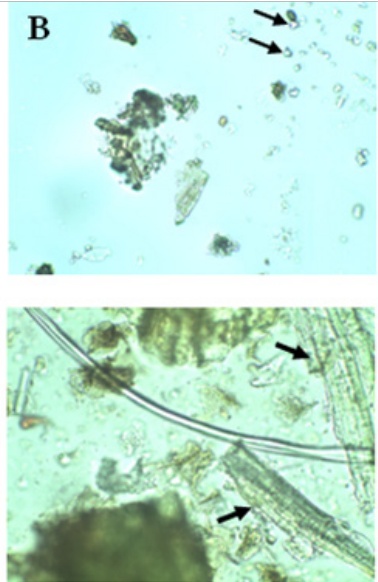
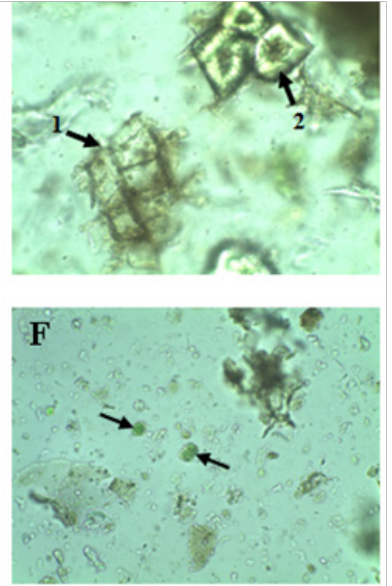

Figure 2 Micrograph of the powder of dry bark of Vernonia conferta: observation with water. (A) I. Conductive tissues. 2. Cluster of Liberian fibers. (B) Calcium oxalate crystals. (C) I. Suber. 2. Collenchyme. (D) Fragment of epidermis covered with toothbrushes. (E) Sclerotized fibers. (F) Primary Perimedullary Screened Tissues (Source: present study).
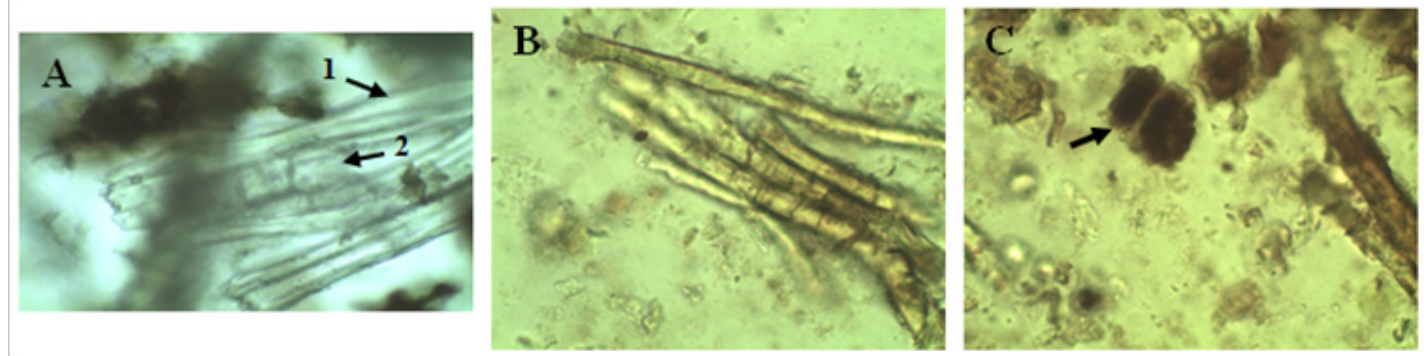

Figure 3 Micrograph of the powder of the dry bark of Petersianthus macrocarpus: observation with water. (A) I. Conductive tissues. 2. Secondary Xylem. (B) Fibers of the palissadic tissue. (C) Sclerous cells. (Source: present study).

Citation: Rose NM, NoëlWM, Denis W, et al. Pharmacognosic standardization of a traditional recipe for incurable wounds based on Petersianthus macrocarpus (Lecythidaceae),Vernonia conferta (Asteraceae), and Carica papaya (Caricaceae) in Cameroon . Pharm Pharmacol Int J. 2019;7(2):86-91. 
The various powders were then extracted using 02 solvent systems: water and an ethanol-water mixture $(70 / 30, \mathrm{v} / \mathrm{v})$. We obtained relatively high extraction yields, which are very important because it facilitates the valorization of the recipe: it was proven that the medical material will always be sufficient for the manufacture of improved traditional medicines. The subsequent phytochemical screening revealed the presence of few secondary metabolites, mainly alkaloids, tannins, saponosides, terpenoids and bound quinones (Table 3 ). These metabolites play an important role in the wound healing process by an amazing virtue of analgesic (alkaloids), antibacterial (tannins), and detersive, anti-inflammatory and antifungal properties (saponosides). ${ }^{17}$

Previous results from screening done by Kunle et al., ${ }^{17}$ on various extracts of plants from the genus Vernonia reinforce our knowledge in the richness of this group in alkaloids, flavonoids, steroids and terpenoids. N'guessan et al., ${ }^{18}$ found in extracts of Petersianthus macrocarpus, large amounts of polyphenols, flavonoids, catechic tannins, alkaloids and saponosides. Mabeku et al., ${ }^{19}$ found a similar result and also sterols. Verma et al., ${ }^{20}$ found in the aqueous extract of dry roots of Carica papaya tannins, sterols and cardiotonic glycosides, while Yusha et al., ${ }^{21}$ observed tannins and saponosides in the aqueous extract of dry leaves. These differences in composition could be explained by the location and the period of the harvest, as well as by the nature of the plant part analyzed.

Physicochemical testing's carried out on these plants allow us to determine for each, the percentages of loss on desiccation and total ash (Table 4). We obtained for Vernonia bark powder a loss on drying of $9.33 \%$, a value close to that was obtained by Kunle et al., ${ }^{17}$ on the entire plant of Vernonia ambigua $(8.20 \%)$; the total ash content is $7 \%$, similar to that of Singh et al. ${ }^{15}$ for the trunk bark of Vernonia cinerea $(6.08 \pm 1 \%)$. For Petersianthus macrocarpus bark powder, results were $8.67 \%$ for loss on drying and $5.2 \%$ for total ash. Satish et al., ${ }^{22}$ obtained different significantly values, $12 \%$ and $14 \%$ respectively for the barks of Careya arborea. This difference is probably due to the fact that the 02 species which belong to the same subfamily are from different genus. The specificities of the bark will not necessarily be the same. We obtained for the fresh roots of Carica papaya a loss on drying of $42.67 \%$ and a total ash content of $11 \%$. Roy et al., ${ }^{13}$ obtained a total ash content for the trunk bark of Carica papaya (10\%): the rather high value of the water content can be explained by the fresh state of the plant sample.

\section{Conclusion}

This work is part of the valorization of research on medicinal plants, traditional remedies and the development of Traditional ameliorated Medicines, from Traditional knowledge, through the standardization of recipes, in use by traditional healers within long generations. Minyem, moreover, has done a similar job relying on a local herbal recipe traditionally used to treat scalp fungal dermatitis. ${ }^{23}$ After a pharmacognosic analysis as complete as possible, we were able to set up a monograph of each of the plants, giving information on their macroscopic characteristics, their microscopic structures, their chemical composition, as well as their water and total ash contents according to the European Pharmacopoeia. Phytochemical screening revealed the presence of alkaloids, tannins, saponosides, terpenoids and quinones. These metabolites play a role in the healing process of wounds through their analgesic (alkaloids), antibacterial (tannins), detersive, anti-inflammatory and antifungal (saponoside) properties. In addition, terpenoids which are principles of essential oils, presents in these plants, act by their antiseptic power against various pathogens, including strains usually antibiotic resistant; Some have also been active on fungi of the genus Candida. ${ }^{24}$ All these properties could actually explain the use of these three plants in the treatment of chronic wounds. All these results could contribute to be part of the future Cameroon Native Pharmacopoeia.

\section{Acknowledgments}

We would like to thank Pr Denis WOUESSIDJEWE and Dr. Rose NGONO MBALLA for the supervision and contribution in the development of this publication. Our thanks also go to Prof. Joseph NGOUPAYO, Dr Aude Perrine MINYEM, and Victorine BEYENE for the participation and follow-up in this study. We will not fail to thank the Laboratory of Pharmacognosy of the University of the Mountains and also the Cameroon National Drug Quality Control and Valuation Laboratory (LANACOME), for the technical platform.

\section{Conflicts of interest}

Authors declare that there is no conflict of interest.

\section{References}

1. Abondo-Ngono R, Tchindjang M, Essi MJ, et al. Cartography of actors of traditional medicine in Cameroon: case of the central region. Ethnopharmacologia. 2015;53:56-63.

2. Rose Ngono Mballa Abondo, Aude Perine Minyem Ngombi, Joseph Ngoupayo, et al. Pharmacognosy and phytochemical standardizationof Albizia ferruginea (Guil and Perr). Journal of Pharmacognosy and Phytotherapy. 2018;10(2):27-33.

3. Minyem Ngombi AP, Ngono Mballa Abondo R, Ngoupayo J, et al. Standardization of Newbouldia laevis Powdered Pulps. Health Sci Dis. 2018;19(4):20

4. Téot L. Wounds, bandages and pains of care. Pain caused by care: 2 nd day of the CNRD; 2007.

5. High Authority of Health. Dressings: indications and recommended uses. Good use of medical technologies. 2011;2009-01.

6. Nielsen L, Fogh K. Clinical utility of foam dressings in wound management: a review. Chronic Wound Care Management and Research. $2015 ; 2015(2): 31-38$

7. Kouadio NJ, Guessennd NK, Kone NW, et al. Evaluation of leaf activity of Mallotus oppositifolius (Geisel.) Müll.-Arg (Euphorbiaceae) on multiresistant bacteria and phytochemical screening. International Journal of Biological and Chemical Sciences. 2015;9(3):1252-1262.

8. Observatory of health in Africa: Traditional medicine. Review of the WHO Regional Office for Africa; 2003.

9. Chabrier JY. Medicinal plants and forms of use in herbal medicine. Université Henri Poincaré; 2010. 183 p.

10. Quality control methods for herbal materials. Switzerland: WHO Press; 2011. 187 p.

11. Blond A, Boutefnouchet S, Cachet X, et al. Pharmacognosia: Guide to practical work grade 3. Université Paris Descartes; 2013/2014. 22 p.

12. Bekro YA, Mamyrbekova J, Boua BB, et al. Ethnobotanical study and phytochemical screening of Caesalpinia benthamiana (Lease) Herend. and Zarucchi (Caesalpiniaceae). Science \& Nature. 2007;4(2):217-225. 
13. Roy SD, Goswami R, Das S, et al. Pharmacognostic Evaluation and Anthelmintic Activity of Leaf and Stem Extract of Carica papaya. Journal of Pharmacy Research. 2012;5(9):4763-4766.

14. Evans CIK, Okoli B, Nwachukwu CU. Epidermal studies of three species of Vernonia Schreb. in Southern Nigeria. Biodiversitas. 2014;15(2):137-141.

15. Singh A, Saharan VA, Kumawat IC, et al. A pharmacognostical study of Vernonia cinerea Less (Asteraceae) and evaluation of anti-inflammatory and antibacterial activities of stem. Egyptian Pharmaceutical Journal. 2014;13(2):104-112

16. Lens F, Baas P, Jansen S, et al. A search for phylogenetically informative wood characters within Lecythidaceae sl. Am J Bot. 2007;94(4):483-502.

17. Kunle OF, Egharevba HO. Preliminary studies on Vernonia ambigua: phytochemical and antimicrobial screening of the whole plant Ethnobotanical Leaflets. 2009;2009(10):2.

18. N'Guessan K, Kadja B, Zirihi G, et al. Phytochemical screening of some Ivorian medicinal plants used in Krobou country (Agboville, Ivory Coast). Science \& Nature. 2009;6(1).
19. Mabeku LBK, Roger KJ, Louis OEJ. Screening of some plants used in the cameroonian folk medicine for the treatment of infectious diseases. International Journal of Biology. 2011;3(4):13.

20. Verma KS, Kaushal VS. Phytochemical profiling of stem and root of Carica papaya Linn for use as potential drugs. Journal of Environment and Social Science Research. 2014;3:1-6.

21. Yusha'u M, Onuorah F, Murtala Y. In vitro sensitivity pattern of some urinary tract isolates to Carica papaya extracts. Bayero Journal of Pure and Applied Sciences. 2009;2(2):75-78

22. Satish KB, Vrushabendra SB, Kamal KG, et al. Review on Careya Arborea ROXB. International Journal of Research in Ayurveda \& Pharmacy. 2010;1(2):306-315.

23. Minyem Ngombi AP. Standardization of a recipe based on Albizia ferruginea and Newbouldia laevis trunk bark and galenic formulation of a topical gel for the treatment of dermatoses [Thesis]. Pharmacy: Faculty of Medicine and Biomedical Sciences of Yaoundé; 2016. 93 p.

24. Bruneton J. Pharmacognosy, phytochemistry, medicinal plants. 4th ed. France: Tec \& Doc Lavoisier; 2009. 